\title{
Sumber dan Frekuensi Aplikasi Larutan Hara sebagai Pengganti AB Mix pada Budidaya Sayuran Daun secara Hidroponik
}

\author{
Application Frequency and Nutrient Sources as AB Mix Substitution for \\ Hydroponics Leafy Vegetables
}

Fita Lita Ramadiani ${ }^{{ }^{*}}$ dan Anas D. Susila ${ }^{1}$

Diterima 15 November 2013/Disetujui 14 Januari 2014

\begin{abstract}
This study was aimed to determine the frequency and source of nutrient applications on growth and yield of spinach (Ipomoea $\mathrm{sp}$.), caisin (Brassica juncea), and kailan (Brassica oleraceae var. acephala) in hydroponics. The experiment were arranged in a RCBD (Randomized Completely Block Design) with two factors, first factor source of nutrient (AB Mix, NPK 15:15:15, and NPK 12:14:12), and second factor is time of application (one time and two time) with four replications so there are 24 experimental units. The result showed NPK 15:15:15 had similar effect with AB Mix in spinach, caisin, and kailan. With one time frequency of application, the best source of fertilizer is NPK 15:15:15, while with two time application is AB Mix.
\end{abstract}

Keywords: compound fertilizer, NPK 12:14:12, NPK 15:15:15, nutrient solution.

\section{ABSTRAK}

Penelitian ini bertujuan untuk mengetahui frekuensi aplikasi dan jenis sumber hara pada pertumbuhan dan produksi kangkung (Ipomoea sp.), caisin (Brassica juncea), dan kailan (Brassica oleraceae var. acephala) secara hidroponik. Rancangan percobaan yang digunakan adalah Rancangan Kelompok Lengkap Teracak (RKLT) dua faktor. Faktor pertama yaitu jenis sumber hara (AB Mix, NPK 15:15:15, dan NPK 12:14:12) dan faktor kedua frekuensi aplikasi (satu kali dan dua kali). Setiap perlakuan diulang empat kali sehingga terdapat 24 satuan percobaan. Secara umum perlakuan NPK 15:15:15 menghasilkan tanaman yang tidak berbeda dengan AB Mix, sedangkan NPK 12:14:12 menghasilkan tanaman dengan kualitas yang paling rendah. Baik frekuensi aplikasi satu kali maupun dua kali menghasilkan tanaman yang sama. Terdapat interaksi antara jenis larutan hara NPK 15:15:15 dengan frekuensi aplikasi satu kali dan jenis hara AB Mix dengan frekuensi aplikasi dua kali.

Kata kunci: larutan hara, NPK 12:14:12, NPK 15:15:15, pupuk majemuk

\section{PENDAHULUAN}

Produksi sayuran nasional mengalami peningkatan pada tahun 2012 sebesar $0.15 \%$ dari produksi sebelumnya pada tahun 2011, namun konsumsi perkapita hanya sebesar 47.3 $\mathrm{kg}$ masih jauh dari standar konsumsi yang direkomendasikan oleh Food and Agriculture Organization (FAO) yaitu $73 \mathrm{~kg}$ per kapita per tahun (BPS, 2013). Menurut Marwan (2008) peningkatan jumlah konsumsi harus diiringi dengan jumlah produksi untuk mengimbangi permintaan sayuran yang menuntut adanya pengadaan sayuran bermutu.

Hidroponik merupakan salah satu cara alternatif budidaya untuk peningkatan kualitas sayuran yang dihasilkan. Menurut Resh (1999) budidaya hidroponik mempunyai beberapa keuntungan dibandingkan dengan budidaya ditanah, yaitu hara tanaman lebih homogen

${ }^{1}$ Departemen Agronomi dan Hortikultura, Faktultas Pertanian, Institut Pertanian Bogor

Jl. Meranti, Kampus IPB Dramaga, Bogor 16680, Indonesia

*email penulis untuk korespondensi: litafita99@yahoo.com 
dan dapat dikendalikan, tidak dibatasi oleh ketersediaan unsur hara dalam tanah, tidak memerlukan pengolahan tanah, penggunaan pupuk lebih efisien, media tanam lebih permanen karena dapat digunakan untuk jangka waktu yang lama, dan hama penyakit cenderung berkurang.

Penelitian Kusumawardhani dan Widodo (2003) dengan menggunakan pupuk majemuk yaitu NPK (20:20:20) dan NPK (8:10:13) dengan penyetaraan unsur $\mathrm{N}$, memberikan hasil yang tidak berbeda nyata dengan larutan hara $\mathrm{AB}$ Mix pada budidaya tomat secara hidroponik. Ditambahkan oleh Iqbal (2006) dan Masriah (2006) bahwa pada budidaya bayam dan kangkung secara hidroponik menggunakan pupuk majemuk NPK (20:20:20) dan NPK (16:20:0) dengan konsentrasi $\mathrm{N}$ yang telah disetarakan dengan larutan hara $\mathrm{AB}$ Mix memiliki hasil yang lebih tinggi dibanding tanaman yang diberi larutan AB Mix. Menurut Noor (2006) air dan hara yang diaplikasikan dalam fertigasi sangat berpengaruh terhadap pertumbuhan dan perkembangan tanaman.

Penelitian-penelitian sebelumnya telah menunjukkan bahwa pupuk majemuk cukup baik untuk tanaman sayuran yang ditanam secara hidroponik, namun harganya masih terlalu mahal untuk budidaya sayuran daun secara komersil. Perlu dilakukan penelitian dengan menggunakan jenis pupuk yang harganya lebih terjangkau. Penelitian ini bertujuan untuk mengetahui frekuensi aplikasi dan jenis sumber hara dengan penyetaraan unsur $\mathrm{N}$ sebagai alternatif pengganti larutan hara $\mathrm{AB}$ Mix pada budidaya kangkung (Ipomoea sp.), caisin (Brassica juncea), dan kailan (Brassica oleraceae Var. Acephala) secara hidroponik.

\section{BAHAN DAN METODE}

Penelitian dilaksanakan pada Maret sampai Mei 2013. Penanaman kangkung, caisin, dan kailan dilakukan di Greenhouse Unit Lapangan Cikabayan, University Farm IPB pada ketinggian $250 \mathrm{~m}$ dpl dengan titik koordinat 6033'5.68" LS dan 106 $42^{\circ}$ '51.33" BT. Dilanjutkan dengan perhitungan bobot di Laboratorium Pasca Panen Departemen Agronomi dan Hortikultura Fakultas Pertanian Institut Pertanian Bogor. Bahan yang digunakan dalam penelitian ini adalah benih kangkung varietas Walet, benih caisin varietas Tosakan, benih kailan varietas Nova, pupuk AB Mix, pupuk NPK (15:15:15), NPK (12:14:12), Carbofuran, Deltametrin, dan arang sekam. Peralatan yang digunakan adalah polybag ukuran $40 \mathrm{~cm}$ x $40 \mathrm{~cm}$, gelas ukur $100 \mathrm{ml}$, timbangan digital, sprayer, kontainer 120 liter, penggaris, kamera, Bagan Warna Daun, EC meter, $\mathrm{pH}$ meter, jangka sorong, dan tray semai.

Rancangan Percobaan yang digunakan adalah Rancangan Kelompok Lengkap Teracak (RKLT) Faktorial dengan dua faktor. Faktor pertama yaitu jenis sumber hara yang terdiri atas pupuk AB Mix (P0), NPK 15:15:15 (P1), dan NPK 12:14:12 (P2). Faktor kedua merupakan frekuensi pemupukan yang terdiri dari 2 perlakuan yaitu: satu kali penyiraman dengan $300 \mathrm{ml}$ dan dua kali penyiraman masing-masing $150 \mathrm{ml}$.

Setiap perlakuan diulang sebanyak 4 ulangan sehingga terdapat 24 satuan percobaan. Setiap satuan percobaan terdiri dari 3 polybag, setiap polybag terdiri dari 4 tanaman, sehingga total tanaman yang ditanam sebanyak 288 untuk masing-masing komoditas. Pengamatan dipilih secara acak 3 tanaman contoh dalam setiap ulangan, total tanaman sampel sebanyak 72 tanaman untuk setiap komoditas yang ditanam. Apabila analisis ragam dengan uji $\mathrm{F}$ pada taraf nyata $5 \%$ untuk perlakuan pemupukan dan frekuensi aplikasi menunjukkan pengaruh yang nyata, maka dilakukan uji lanjut dengan uji jarak berganda Duncan Multiple Range Test (DMRT) pada taraf nyata 5\%.

Penelitian akan dilakukan secara terpisah antara masing-masing komoditas. Benih caisin, kangkung, dan kailan akan disemai dalam tray dengan media berupa cascing. Setelah berumur 2-3 minggu, bibit akan dipindah-tanamkan di greenhouse. Pindah tanam setelah penyemaian dilakukan kedalam polybag ukuran $40 \mathrm{~cm}$ x 40 $\mathrm{cm}$ dengan media arang sekam. Penyiraman dan pemupukan untuk pupuk AB Mix, NPK (15:15:15), dan NPK (12:14:12) dilakukan secara bersamaan dengan sistem fertigasi manual. Larutan pupuk majemuk NPK (15:15:15) dan NPK (12:14:12) disetarakan kandungan $\mathrm{N}$-nya dengan kandungan $\mathrm{N}$ pada larutan hara AB Mix (180 $\left.\mathrm{mg} \mathrm{l}^{-1} \mathrm{~N}\right)$. Setelah disetarakan akan didapatkan pupuk NPK (15:15:15) sebanyak $1.2 \mathrm{~g} \mathrm{l}^{-1}$ dan NPK (12:14:12) sebanyak $1.5 \mathrm{~g} \mathrm{l}^{-1}$. Pupuk AB Mix dilarutkan dalam kontainer A dan kontainer B dengan volume masing-masing 90 liter. Sebanyak 250 $\mathrm{ml}$ masing-masing larutan stok diencerken 
pada kontainer berukuran 120 liter. Perlakuan pertama diaplikasikan 1 kali sehari sebanyak $300 \mathrm{ml}$ sedangkan perlakuan kedua diaplikasikan 2 kali pada pagi dan sore hari masingmasing $150 \mathrm{ml}$ dengan menggunakan gelas ukur. Pemeliharaan tanaman meliputi pengendalian hama dan penyakit. Kangkung, caisin, dan kailan dapat dipanen pada umur 34 MST.

\section{HASIL DAN PEMBAHASAN}

Suhu rata-rata di dalam rumah kaca selama penelitian cukup tinggi yaitu berkisar antara $26-40{ }^{\circ} \mathrm{C}$. Suhu tersebut mengakibatkan tanaman mengalami layu tidak permanen. Penelitian ini menunjukkan bahwa perlakuan jenis hara berpengaruh nyata terhadap keseluruhan parameter pengamatan, baik pengamatan vegetatif maupun panen Perlakuan frekuensi aplikasi tidak berpengaruh nyata terhadap seluruh parameter pengamatan.

\section{Kangkung Periode I}

Jenis hara berpengaruh nyata pada diameter batang 2-3 MST, lebar daun 1-3 MST, panjang daun 2-3 MST, dan jumlah daun 1-3 MST (Tabel 1 dan 2). Jenis hara AB Mix, NPK 15:15:15, dan NPK 12:14:12 menghasilkan tinggi tanaman yang tidak berbeda nyata hingga akhir penelitian. NPK 15:15:15 menghasilkan lebar daun, panjang daun, dan jumlah daun yang lebih tinggi dibandingkan AB Mix dan NPK 12:14:12. Diameter batang pada 1-3 MST dengan jenis hara AB Mix tidak berbeda dengan NPK 15:15:15. Sementara itu, NPK 12:14:12 menghasilkan tanaman yang paling rendah.

Tabel 1. Pengaruh hara dan frekuensi aplikasi terhadap tinggi tanaman, diameter batang, dan lebar daun kangkung

\begin{tabular}{|c|c|c|c|c|c|c|c|c|c|}
\hline \multirow{2}{*}{ Perlakuan } & \multicolumn{3}{|c|}{ Tinggi Tanaman (cm) } & \multicolumn{3}{|c|}{ Diameter Batang (cm) } & \multicolumn{3}{|c|}{ Lebar Daun $(\mathrm{cm})$} \\
\hline & $1 \mathrm{MST}$ & $2 \mathrm{MST}$ & $3 \mathrm{MST}$ & $1 \mathrm{MST}$ & $2 \mathrm{MST}$ & $3 \mathrm{MST}$ & $1 \mathrm{MST}$ & $2 \mathrm{MST}$ & $3 \mathrm{MST}$ \\
\hline \multicolumn{10}{|l|}{ Hara } \\
\hline AB Mix & 11.09 & 17.73 & 27.09 & 0.25 & $0.33 \mathrm{ab}$ & $0.40 \mathrm{a}$ & $1.03 \mathrm{~b}$ & $1.44 \mathrm{~b}$ & $1.63 b$ \\
\hline NPK 15:15:15 & 12.15 & 19.07 & 28.32 & 0.25 & $0.34 \mathrm{a}$ & $0.42 \mathrm{a}$ & $1.20 \mathrm{a}$ & $1.79 \mathrm{a}$ & $2.18 \mathrm{a}$ \\
\hline NPK 12:14:12 & 12.39 & 18.69 & 26.13 & 0.25 & $0.32 \mathrm{~b}$ & $0.36 \mathrm{~b}$ & $1.11 \mathrm{ab}$ & $1.50 \mathrm{~b}$ & $1.73 b$ \\
\hline P-value & tn & tn & tn & tn & $*$ & $* *$ & $*$ & $* *$ & $* *$ \\
\hline \multicolumn{10}{|l|}{ Frekuensi } \\
\hline $1 \mathrm{kali}$ & 11.97 & 18.62 & 27.39 & 0.25 & 0.33 & 0.39 & 1.09 & 1.58 & 1.86 \\
\hline 2 kali & 11.78 & 18.38 & 26.96 & 0.25 & 0.33 & 0.39 & 1.14 & 1.57 & 1.83 \\
\hline P-value & tn & tn & tn & tn & tn & tn & tn & tn & th \\
\hline \multicolumn{10}{|l|}{ Interaksi } \\
\hline P-value & tn & $\operatorname{tn}$ & tn & tn & tn & tn & tn & tn & $\operatorname{tn}$ \\
\hline $\mathrm{CV}$ & 11.76 & 7.05 & 9.62 & 6.26 & 4.95 & 7.54 & 10.93 & 12.30 & 11.28 \\
\hline
\end{tabular}

Tabel 2. Pengaruh hara dan frekuensi aplikasi terhadap panjang daun dan jumlah daun kangkung

\begin{tabular}{|c|c|c|c|c|c|c|}
\hline \multirow{2}{*}{ Perlakuan } & \multicolumn{3}{|c|}{ Panjang Daun $(\mathrm{cm})$} & \multicolumn{3}{|c|}{ Jumlah Daun (helai) } \\
\hline & $1 \mathrm{MST}$ & $2 \mathrm{MST}$ & $3 \mathrm{MST}$ & $1 \mathrm{MST}$ & $2 \mathrm{MST}$ & $3 \mathrm{MST}$ \\
\hline \multicolumn{7}{|l|}{ Hara } \\
\hline AB Mix & 5.73 & $7.68 b$ & $8.59 \mathrm{~b}$ & $2.83 \mathrm{~b}$ & $6.83 \mathrm{ab}$ & $8.75 b$ \\
\hline NPK 15:15:15 & 6.08 & $8.49 \mathrm{a}$ & $9.85 \mathrm{a}$ & $3.29 \mathrm{a}$ & $7.29 \mathrm{a}$ & $9.79 \mathrm{a}$ \\
\hline NPK 12:14:12 & 5.73 & $7.74 b$ & $8.53 \mathrm{~b}$ & $2.58 \mathrm{~b}$ & $6.29 b$ & $9.08 \mathrm{~b}$ \\
\hline P-value & tn & $*$ & $*$ & $* *$ & $* *$ & $* *$ \\
\hline \multicolumn{7}{|l|}{ Frekuensi } \\
\hline 1 kali & 5.83 & 8.01 & 9.11 & $2.94 a$ & $6.83 \mathrm{a}$ & $9.25 \mathrm{a}$ \\
\hline 2 kali & 6.04 & 7.93 & 8.87 & $2.86 \mathrm{a}$ & $6.78 \mathrm{a}$ & $9.17 \mathrm{a}$ \\
\hline P-value & tn & tn & tn & tn & tn & tn \\
\hline \multicolumn{7}{|l|}{ Interaksi } \\
\hline P-value & tn & tn & tn & tn & tn & tn \\
\hline CV & 7.02 & 7.87 & 10.76 & 13.13 & 7.48 & 5.71 \\
\hline
\end{tabular}

Keterangan: angka yang diikuti huruf yang sama pada kolom yang sama tidak berbeda nyata menurut uji DMRT 5\% 
Hal ini diduga karena NPK 12:14:12 hanya mengandung unsur hara makro $\mathrm{N}, \mathrm{P}, \mathrm{K}$, dan $\mathrm{Mg}$ serta hara mikro yaitu $\mathrm{Mn}, \mathrm{B}, \mathrm{Cu}, \mathrm{Co}$, dan Zn. Sedangkan NPK 15:15:15 mengandung hara makro N, P, K, Mg, dan S yang hampir setara dengan AB Mix. Menurut Salisbury dan Ross (1995), jika tanaman kekurangan salah satu dari unsur yang dibutuhkan maka tanaman tidak akan dapat menyelesaikan siklus hidupnya karena unsur tersebut berperan langsung dalam kehidupan tanaman dan kedudukannya tidak dapat digantikan oleh unsur lain.

Perlakuan jenis hara berpengaruh sangat nyata terhadap bobot tanaman ${ }^{-1}$, bobot 4 tanaman ${ }^{-1}$, bobot daun, bobot batang, bobot akar, panjang akar, bobot total, dan warna daun (Tabel 3 dan 4). Jenis hara berpengaruh nyata terhadap bobot layak pasar, tetapi tidak berpengaruh nyata terhadap bobot tidak layak pasar (Tabel 3 dan 4). Bobot tanaman ${ }^{-1}$, bobot 4 tanaman $^{-1}$, bobot/total, bobot layak pasar, bobot daun, bobot batang, dan bobot akar yang dihasilkan pada jenis hara NPK 15:15:15 lebih tinggi dibandingkan AB Mix dan NPK 12:14:12. Sementara pada panjang akar dan warna daun yang dihasilkan jenis hara NPK 15:15:15 tidak berbeda dengan AB Mix. NPK 12:14:12 menghasilkan tanaman yang rendah kualitas-nya. NPK 12:14:12 memiliki warna daun yang agak kekuning-kuningan. Hal ini diduga tanaman kangkung kekurangan unsur sulfur. Gejala-gejala tanaman yang kekurangan unsur sulfur menurut Munawar (2011) yaitu daun-daun muda berwarna kuning pucat, sementara daun-daun tua masih berwarna hijau.

Tabel 3. Pengaruh hara dan frekuensi aplikasi terhadap bobot tanaman ${ }^{-1}$, bobot $4 \operatorname{tanaman}^{-1}$, bobot layak pasar, bobot tidak layak pasar, dan bobot/total kangkung

\begin{tabular}{|c|c|c|c|c|c|}
\hline \multirow[b]{2}{*}{ Perlakuan } & \multirow{2}{*}{$\begin{array}{c}\text { Bobot } \\
\text { Tanaman }^{-1} \\
(\mathrm{~g})\end{array}$} & \multirow[b]{2}{*}{$\begin{array}{c}\text { Bobot } 4 \\
\operatorname{Tanaman}^{-1}(\mathrm{~g})\end{array}$} & \multicolumn{3}{|c|}{ Bobot 96 Tanaman $(\mathrm{g})$} \\
\hline & & & $\begin{array}{c}\text { Bobot Layak } \\
\text { Pasar }\end{array}$ & $\begin{array}{c}\text { Bobot Tidak Layak } \\
\text { Pasar }\end{array}$ & Bobot Tota \\
\hline \multicolumn{6}{|c|}{ (2) } \\
\hline AB Mix & $6.12 b$ & $22.58 \mathrm{~b}$ & $2.91 \mathrm{~b}$ & 64.83 & $67.74 b$ \\
\hline NPK $15: 15: 15$ & $9.21 \mathrm{a}$ & $33.64 \mathrm{a}$ & $24.93 a$ & 76.03 & $100.96 a$ \\
\hline NPK 12:14:12 & $5.68 \mathrm{~b}$ & $22.16 \mathrm{~b}$ & $0.00 \mathrm{~b}$ & 66.51 & $66.51 \mathrm{~b}$ \\
\hline P-value & $* *$ & $* *$ & $*$ & tn & $* *$ \\
\hline \multicolumn{6}{|l|}{ Frekuensi } \\
\hline 1 kali & 7.04 & 25.03 & 6.22 & 68.85 & 75.07 \\
\hline 2 kali & 6.97 & 27.23 & 12.34 & 69.39 & 81.73 \\
\hline P-value & tn & tn & tn & tn & tn \\
\hline \multicolumn{6}{|l|}{ Interaksi } \\
\hline P-value & tn & tn & tn & tn & tn \\
\hline $\mathrm{CV}$ & 19.59 & 18.51 & 170.14 & 17.90 & 18.52 \\
\hline
\end{tabular}

Keterangan: angka yang diikuti huruf yang sama pada kolom yang sama tidak berbeda nyata menurut uji DMRT 5\%

Tabel 4. Pengaruh hara dan frekuensi aplikasi terhadap bobot daun, bobot batang, bobot akar, panjang akar, dan warna daun kangkung

\begin{tabular}{|c|c|c|c|c|c|}
\hline \multirow{2}{*}{ Perlakuan } & \multicolumn{3}{|c|}{ Bobot Tanaman $^{-1}(\mathrm{~g})$} & \multirow{2}{*}{$\begin{array}{c}\text { Panjang Akar } \\
(\mathrm{cm})\end{array}$} & \multirow{2}{*}{ Warna Daun } \\
\hline & Daun & Batang & Akar & & \\
\hline \multicolumn{6}{|l|}{ Hara } \\
\hline AB Mix & $2.28 \mathrm{~b}$ & $2.92 b$ & $1.05 \mathrm{~b}$ & $14.51 \mathrm{a}$ & $3.00 \mathrm{a}$ \\
\hline NPK 15:15:15 & $3.80 \mathrm{a}$ & $3.69 \mathrm{a}$ & $1.54 \mathrm{a}$ & $14.85 \mathrm{a}$ & $3.00 \mathrm{a}$ \\
\hline NPK 12:14:12 & $2.05 b$ & $2.49 b$ & $0.76 \mathrm{c}$ & $12.64 b$ & $2.54 \mathrm{~b}$ \\
\hline $\mathrm{P}$-value & $* *$ & $* *$ & $* *$ & $* *$ & $* *$ \\
\hline \multicolumn{6}{|l|}{ Frekuensi } \\
\hline $1 \mathrm{kali}$ & 2.70 & 3.02 & 1.12 & 14.38 & 2.81 \\
\hline 2 kali & 2.72 & 3.04 & 1.12 & 13.63 & 2.89 \\
\hline $\mathrm{P}$-value & $\operatorname{tn}$ & tn & tn & tn & tn \\
\hline \multicolumn{6}{|l|}{ Interaksi } \\
\hline P-value & tn & tn & tn & tn & tn \\
\hline $\mathrm{CV}$ & 25.82 & 14.28 & 20.40 & 11.86 & 9.13 \\
\hline
\end{tabular}

Keterangan: angka yang diikuti huruf yang sama pada kolom yang sama tidak berbeda nyata menurut uji DMRT 5\% 
Hal ini dikarenakan dalam hara NPK 12:14:12 tidak mengandung unsur sulfur seperti NPK 15:15:15 dan AB Mix. Frekuensi aplikasi tidak berpengaruh nyata terhadap seluruh parameter pengamatan baik pada pertumbuhan vegetatif maupun panen. Tidak terdapat interaksi diantara kedua perlakuan terhadap seluruh parameter pengamatan vegetatif dan panen.

\section{Caisin}

Perlakuan jenis hara berpengaruh sangat nyata terhadap diameter batang 1-4 MST, dan jumlah daun 3-4 MST, serta berpengaruh nyata pada jumlah daun 1 MST (Tabel 5 dan 6).
Jenis hara tidak berpengaruh nyata terhadap tinggi tanaman, lebar daun, dan panjang daun. Jenis hara $\mathrm{AB}$ Mix pada diameter batang merupakan yang tertinggi, NPK 15:15:15 merupakan kedua tertinggi, dan NPK 12:14:12 yang terendah. Secara umum, pada pertumbuhan vegetatif dengan perlakuan NPK 15:15:15 menghasilkan tanaman yang tidak berbeda nyata dengan $\mathrm{AB}$ Mix. Hal ini selaras dengan penelitian Iqbal (2006) yang menyatakan bahwa tanaman bayam yang diberi larutan hara yang berasal dari pupuk majemuk memiliki tinggi, diameter, dan bobot tajuk yang sama dengan AB Mix.

Tabel 5. Pengaruh hara dan frekuensi aplikasi terhadap tinggi tanaman, diameter batang, dan lebar daun caisin

\begin{tabular}{|c|c|c|c|c|c|c|c|c|c|c|c|c|}
\hline \multirow{3}{*}{ Perlakuan } & \multicolumn{5}{|c|}{ Tinggi Tanaman $(\mathrm{cm})$} & \multicolumn{5}{|c|}{ Diameter Batang (cm) } & \multicolumn{2}{|c|}{$\begin{array}{l}\text { Lebar Daun } \\
\qquad(\mathrm{cm})\end{array}$} \\
\hline & 1 & 2 & 3 & 4 & 1 & 2 & 3 & 4 & 1 & 2 & 3 & 4 \\
\hline & MST & MST & MST & MST & MST & MST & MST & MST & MST & MST & MST & MST \\
\hline \multicolumn{13}{|l|}{ Hara } \\
\hline AB Mix & 2.41 & 2.80 & 3.03 & 3.39 & 0.27 & $0.37 \mathrm{a}$ & $0.43 \mathrm{a}$ & $0.56 \mathrm{a}$ & 3.38 & 4.38 & 4.75 & 4.90 \\
\hline NPK 15:15:15 & 2.29 & 2.62 & 2.83 & 3.17 & 0.26 & $0.36 \mathrm{a}$ & $0.40 \mathrm{~b}$ & $0.49 \mathrm{~b}$ & 3.40 & 4.37 & 4.91 & 5.08 \\
\hline NPK12:14:12 & 2.68 & 3.03 & 3.38 & 3.80 & 0.25 & $0.34 b$ & $0.36 \mathrm{c}$ & $0.44 \mathrm{c}$ & 3.33 & 4.03 & 4.36 & 4.48 \\
\hline P-value & tn & tn & tn & tn & tn & $* *$ & $* *$ & $* *$ & tn & tn & tn & tn \\
\hline \multicolumn{13}{|l|}{ Frekuensi } \\
\hline 1 kali & 2.46 & 2.83 & 3.15 & 3.44 & 0.26 & 0.36 & 0.40 & 0.50 & 3.27 & 4.19 & 4.55 & 4.69 \\
\hline 2 kali & 2.46 & 2.80 & 3.01 & 3.47 & 0.26 & 0.36 & 0.40 & 0.49 & 3.47 & 4.33 & 4.79 & 4.94 \\
\hline P-value & tn & tn & tn & tn & tn & tn & tn & tn & tn & tn & tn & tn \\
\hline \multicolumn{13}{|l|}{ Interaksi } \\
\hline $\mathrm{P}$-value & tn & tn & tn & tn & tn & tn & tn & tn & tn & tn & tn & tn \\
\hline $\mathrm{CV}$ & 15.24 & 17.86 & 16.32 & 17.32 & 9.96 & 5.57 & 4.86 & 6.54 & 9.22 & 11.56 & 10.53 & 10.57 \\
\hline
\end{tabular}

Keterangan: angka yang diikuti huruf yang sama pada kolom yang sama tidak berbeda nyata menurut uji DMRT 5\%

Tabel 6. Pengaruh hara dan frekuensi aplikasi terhadap panjang daun dan jumlah daun caisin

\begin{tabular}{|c|c|c|c|c|c|c|c|c|}
\hline \multirow{2}{*}{ Perlakuan } & \multicolumn{4}{|c|}{ Panjang Daun $(\mathrm{cm})$} & \multicolumn{4}{|c|}{ Jumlah Daun (helai) } \\
\hline & $1 \mathrm{MST}$ & $2 \mathrm{MST}$ & $3 \mathrm{MST}$ & $4 \mathrm{MST}$ & $1 \mathrm{MST}$ & $2 \mathrm{MST}$ & $3 \mathrm{MST}$ & $4 \mathrm{MST}$ \\
\hline \multicolumn{9}{|l|}{ Hara } \\
\hline AB Mix & 10.48 & 11.73 & 12.49 & 12.77 & $4.46 a b$ & 6.08 & $7.33 \mathrm{a}$ & $8.75 a$ \\
\hline NPK 15:15:15 & 10.45 & 11.70 & 12.56 & 12.90 & $4.75 \mathrm{a}$ & 6.38 & $7.13 \mathrm{a}$ & $8.33 \mathrm{a}$ \\
\hline NPK 12:14:12 & 9.46 & 10.72 & 11.37 & 11.54 & $4.21 \mathrm{~b}$ & 5.92 & $6.50 \mathrm{~b}$ & $7.00 \mathrm{~b}$ \\
\hline $\mathrm{P}$-value & tn & tn & tn & tn & $*$ & tn & $* *$ & $* *$ \\
\hline \multicolumn{9}{|l|}{ Frekuensi } \\
\hline 1 kali & 10.08 & 11.33 & 12.05 & 12.29 & 4.53 & 5.97 & 6.89 & 7.94 \\
\hline 2 kali & 10.18 & 11.43 & 12.23 & 12.52 & 4.42 & 6.28 & 7.08 & 8.11 \\
\hline P-value & tn & tn & tn & tn & tn & tn & tn & tn \\
\hline \multicolumn{9}{|l|}{ Interaksi } \\
\hline P-value & tn & tn & $\operatorname{tn}$ & tn & tn & tn & tn & tn \\
\hline $\mathrm{CV}$ & 11.98 & 10.70 & 9.85 & 9.79 & 8.78 & 7.21 & 6.49 & 7.69 \\
\hline
\end{tabular}

Keterangan: angka yang diikuti huruf yang sama pada kolom yang sama tidak berbeda nyata menurut uji DMRT 5\% 
Jenis hara berpengaruh sangat nyata terhadap bobot total, bobot 4 tanaman $^{-1}$, bobot daun, dan panjang akar (Tabel 7 dan 8). Perlakuan jenis hara berpengaruh nyata pada bobot tanaman ${ }^{-1}$ dan bobot batang, tetapi tidak berpengaruh nyata pada bobot layak pasar, bobot tidak layak pasar, bobot akar, dan warna daun. Rata-rata perlakuan NPK 15:15:15 menghasilkan panen yang tidak berbeda nyata dengan $\mathrm{AB}$ Mix, kecuali pada bobot batang NPK 15:15:15 lebih rendah dibanding AB Mix. Sementara itu, NPK 12:14:12 menghasilkan panen terendah dibandingkan jenis hara lain. Frekuensi palikasi tidak berpengaruh nyata terhadap seluruh parameter pengamatan. Interaksi antara jenis hara dan frekuensi aplikasi memiliki pengaruh yang tidak nyata terhadap seluruh parameter pengamatan caisin.

Tabel 7. Pengaruh hara dan frekuensi aplikasi terhadap bobot tanaman ${ }^{-1}$, bobot $4 \operatorname{tanaman}^{-1}$, bobot layak pasar, bobot tidak layak pasar, dan bobot total caisin

\begin{tabular}{|c|c|c|c|c|c|}
\hline \multirow[b]{2}{*}{ Perlakuan } & \multirow{2}{*}{$\begin{array}{c}\text { Bobot } \\
\text { Tanaman }^{-1}(\mathrm{~g})\end{array}$} & \multirow{2}{*}{$\begin{array}{c}\text { Bobot } 4 \\
\operatorname{Tanaman}^{-1}(\mathrm{~g})\end{array}$} & \multicolumn{3}{|c|}{ Bobot 96 tanaman $(\mathrm{g})$} \\
\hline & & & $\begin{array}{c}\text { Bobot Layak } \\
\text { Pasar }\end{array}$ & $\begin{array}{c}\text { Bobot Tidak Layak } \\
\text { Pasar }\end{array}$ & $\begin{array}{l}\text { Bobot } \\
\text { Total }\end{array}$ \\
\hline \multicolumn{6}{|l|}{ Hara } \\
\hline AB Mix & $31.82 \mathrm{a}$ & $105.36 \mathrm{a}$ & 184.81 & 131.28 & $316.09 \mathrm{a}$ \\
\hline NPK 15:15:15 & $24.05 \mathrm{ab}$ & $100.04 \mathrm{a}$ & 122.79 & 177.34 & $300.13 a$ \\
\hline NPK 12:14:12 & $19.82 b$ & $62.39 \mathrm{~b}$ & 54.98 & 132.19 & $187.17 b$ \\
\hline P-value & $*$ & $* *$ & tn & tn & $* *$ \\
\hline \multicolumn{6}{|l|}{ Frekuensi } \\
\hline 1 kali & 23.15 & 88.94 & 106.48 & 53.67 & 160.15 \\
\hline 2 kali & 27.31 & 89.59 & 135.24 & 44.51 & 179.75 \\
\hline $\mathrm{P}$-value & tn & tn & tn & tn & tn \\
\hline \multicolumn{6}{|l|}{ interaksi } \\
\hline P-value & tn & tn & tn & tn & tn \\
\hline $\mathrm{CV}$ & 33.65 & 25.38 & 82.87 & 38.04 & 25.38 \\
\hline
\end{tabular}

Keterangan: angka yang diikuti huruf yang sama pada kolom yang sama tidak berbeda nyata menurut uji DMRT 5\%

Tabel 8. Pengaruh hara dan frekuensi aplikasi terhadap bobot daun, bobot batang, bobot akar, panjang akar, dan warna daun caisin

\begin{tabular}{|c|c|c|c|c|c|}
\hline \multirow{2}{*}{ Perlakuan } & \multicolumn{3}{|c|}{ Bobot Tanaman $^{-1}(\mathrm{~g})$} & \multirow{2}{*}{ Panjang Akar (cm) } & \multirow{2}{*}{ Warna Daun } \\
\hline & Daun & Batang & Akar & & \\
\hline \multicolumn{6}{|l|}{ Hara } \\
\hline AB Mix & $27.21 \mathrm{a}$ & $1.12 \mathrm{a}$ & 2.79 & $14.40 \mathrm{a}$ & 3.00 \\
\hline NPK 15:15:15 & $25.07 \mathrm{a}$ & $0.84 b$ & 2.05 & $15.61 \mathrm{a}$ & 3.00 \\
\hline NPK 12:14:12 & $16.44 \mathrm{~b}$ & $0.78 \mathrm{~b}$ & 1.57 & $10.25 b$ & 3.25 \\
\hline P-value & $* *$ & $*$ & tn & $* *$ & tn \\
\hline \multicolumn{6}{|l|}{ Frekuensi } \\
\hline 1 kali & 22.26 & 0.94 & 1.92 & 14.00 & 3.08 \\
\hline 2 kali & 23.56 & 0.89 & 2.36 & 12.84 & 3.08 \\
\hline P-value & tn & tn & tn & tn & tn \\
\hline \multicolumn{6}{|l|}{ Interaksi } \\
\hline P-value & tn & tn & tn & tn & tn \\
\hline $\mathrm{CV}$ & 25.67 & 27.08 & 44.61 & 17.99 & 8.68 \\
\hline
\end{tabular}

Keterangan: angka yang diikuti huruf yang sama pada kolom yang sama tidak berbeda nyata menurut uji DMRT 5\% 


\section{Kailan}

Perlakuan jenis hara memiliki pengaruh yang sangat nyata terhadap diameter batang 4 MST, lebar daun 1-4 MST, panjang daun 2-4 MST, dan jumlah daun 2-3 MST (Tabel 9 dan 10). Jenis hara berpengaruh nyata terhadap tinggi tanaman 4 MST, diameter batang 1 dan 3 MST, panjang daun 1 MST, serta jumlah daun 1 dan 4 MST, sedangkan pada tinggi tanaman 1-3 MST dan diameter batang 2 MST perlakuan jenis hara tidak berpengaruh nyata (Tabel 9 dan 10). Tinggi tanaman, diameter batang, dan jumlah daun yang dihasilkan jenis hara NPK 15:15:15 tidak berbeda nyata dengan AB Mix, sedangkan pada lebar daun dan panjang daun perlakuan NPK 15:15:15 lebih tinggi dibandingkan $\mathrm{AB}$ Mix.

Berdasarkan tabel 10 jumlah daun dengan perlakuan NPK 15:15:15 pada akhir pengamatan memiliki jumlah daun yang paling sedikit dibandingkan jenis hara lain. Hal ini disebabkan pada minggu keempat terjadi serangan hama kutu kebul (Bemisia tabacii). Kutu kebul biasa menyerang tanaman kubiskubisan. Gejala yang ditimbulkan yaitu daun menguning secara perlahan hampir keseluruh helaian hingga akhirnya daun menguning dan mati. Kutu kebul banyak ditemukan di greenhouse (Capinera, 2001).

Tabel 9. Pengaruh hara dan frekuensi aplikasi terhadap tinggi tanaman, diameter batang, dan lebar daun kailan

\begin{tabular}{|c|c|c|c|c|c|c|c|c|c|c|c|c|}
\hline \multirow[b]{2}{*}{ Perlakuan } & \multicolumn{4}{|c|}{ Tinggi Tanaman $(\mathrm{cm})$} & \multicolumn{4}{|c|}{ Diameter Batang (cm) } & \multicolumn{4}{|c|}{ Lebar Daun (cm) } \\
\hline & $\begin{array}{c}1 \\
\text { MST } \\
\end{array}$ & $\begin{array}{c}2 \\
\text { MST }\end{array}$ & $\begin{array}{c}3 \\
\text { MST }\end{array}$ & $\begin{array}{c}4 \\
\text { MST } \\
\end{array}$ & $\begin{array}{c}1 \\
\text { MST }\end{array}$ & $\begin{array}{c}2 \\
\text { MST }\end{array}$ & $\begin{array}{c}3 \\
\text { MST }\end{array}$ & $\begin{array}{c}4 \\
\text { MST }\end{array}$ & $\begin{array}{c}1 \\
\mathrm{MST}\end{array}$ & $\begin{array}{c}2 \\
\text { MST }\end{array}$ & $\begin{array}{c}3 \\
\text { MST } \\
\end{array}$ & $\begin{array}{c}4 \\
\text { MST }\end{array}$ \\
\hline \multicolumn{13}{|l|}{ Hara } \\
\hline AB Mix & 3.83 & $5.29 \mathrm{ab}$ & 7.40 & $8.75 \mathrm{a}$ & $0.22 \mathrm{ab}$ & $0.25 \mathrm{ab}$ & $0.28 \mathrm{ab}$ & $0.36 \mathrm{a}$ & $3.12 b$ & $3.69 b$ & $3.82 b$ & $3.95 b$ \\
\hline $\begin{array}{l}\text { NPK } \\
15: 15: 15\end{array}$ & 3.89 & $5.61 \mathrm{a}$ & 7.29 & $8.33 \mathrm{a}$ & $0.23 \mathrm{a}$ & $0.26 \mathrm{a}$ & $0.29 \mathrm{a}$ & $0.35 \mathrm{a}$ & $3.59 \mathrm{a}$ & $4.45 \mathrm{a}$ & $4.66 \mathrm{a}$ & $5.27 \mathrm{a}$ \\
\hline $\begin{array}{l}\text { NPK } \\
12: 14: 12\end{array}$ & 3.52 & $4.98 \mathrm{~b}$ & 6.86 & $7.00 \mathrm{~b}$ & $0.21 \mathrm{~b}$ & $0.24 b$ & $0.27 \mathrm{~b}$ & $0.31 b$ & $3.02 b$ & $3.58 \mathrm{~b}$ & $3.67 b$ & $3.75 b$ \\
\hline $\mathrm{P}$-value & $\operatorname{tn}$ & tn & $\operatorname{tn}$ & $*$ & $*$ & tn & $*$ & $* *$ & $* *$ & $* *$ & $* *$ & $* *$ \\
\hline \multicolumn{13}{|l|}{ Frekuensi } \\
\hline 1 kali & 3.69 & 5.09 & 7.01 & 7.94 & 0.23 & 0.25 & 0.28 & 0.35 & 3.20 & 3.83 & 3.99 & 4.19 \\
\hline 2 kali & 3.81 & 5.50 & 7.36 & 8.11 & 0.22 & 0.25 & 0.28 & 0.34 & 3.28 & 3.98 & 4.11 & 4.46 \\
\hline $\mathrm{P}$-value & tn & tn & tn & tn & tn & tn & tn & tn & tn & tn & tn & tn \\
\hline \multicolumn{13}{|l|}{ Interaksi } \\
\hline $\mathrm{CV}$ & 10.90 & 9.01 & 10.67 & 10.69 & 4.10 & 7.12 & 7.11 & 6.05 & 7.99 & 8.91 & 1.06 & 12.93 \\
\hline
\end{tabular}

Keterangan: angka yang diikuti huruf yang sama pada kolom yang sama tidak berbeda nyata menurut uji DMRT 5\%

Tabel 10. Pengaruh hara dan frekuensi aplikasi terhadap panjang daun dan jumlah daun kailan

\begin{tabular}{|c|c|c|c|c|c|c|c|c|}
\hline \multirow{2}{*}{ Perlakuan } & \multicolumn{4}{|c|}{ Panjang Daun $(\mathrm{cm})$} & \multicolumn{4}{|c|}{ Jumlah Daun (helai) } \\
\hline & $1 \mathrm{MST}$ & $2 \mathrm{MST}$ & $3 \mathrm{MST}$ & $4 \mathrm{MST}$ & $1 \mathrm{MST}$ & $2 \mathrm{MST}$ & $3 \mathrm{MST}$ & $4 \mathrm{MST}$ \\
\hline \multicolumn{9}{|l|}{ Hara } \\
\hline AB Mix & $3.74 b$ & $4.26 \mathrm{~b}$ & $4.42 b$ & $4.56 b$ & $3.38 \mathrm{a}$ & $5.17 \mathrm{~b}$ & $6.67 \mathrm{a}$ & $8.29 \mathrm{a}$ \\
\hline NPK 15:15:15 & $4.26 \mathrm{a}$ & $4.81 \mathrm{a}$ & $5.13 \mathrm{a}$ & $5.68 \mathrm{a}$ & $3.50 \mathrm{a}$ & $5.58 \mathrm{a}$ & $6.75 a$ & $7.5 b$ \\
\hline NPK 12:14:12 & $3.55 \mathrm{~b}$ & $3.96 \mathrm{~b}$ & $4.13 b$ & $4.21 \mathrm{~b}$ & $3.08 \mathrm{~b}$ & $4.83 \mathrm{~b}$ & $5.96 \mathrm{~b}$ & $7.63 b$ \\
\hline P-value & $*$ & $* *$ & $* *$ & $* *$ & $*$ & $* *$ & $* *$ & $*$ \\
\hline \multicolumn{9}{|l|}{ Frekuensi } \\
\hline 1 kali & 3.70 & 4.28 & 4.53 & 4.73 & 3.33 & 5.25 & 6.39 & 7.78 \\
\hline 2 kali & 3.99 & 4.41 & 4.60 & 4.90 & 3.31 & 5.14 & 6.53 & 7.83 \\
\hline $\mathrm{P}$-value & tn & tn & tn & tn & tn & tn & tn & tn \\
\hline \multicolumn{9}{|l|}{ Interaksi } \\
\hline $\mathrm{P}$-value & tn & tn & tn & tn & tn & tn & tn & $\operatorname{tn}$ \\
\hline $\mathrm{CV}$ & 11.89 & 8.98 & 9.51 & 11.55 & 7.84 & 6.12 & 6.22 & 7.70 \\
\hline
\end{tabular}

Keterangan: angka yang diikuti huruf yang sama pada kolom yang sama tidak berbeda nyata menurut uji DMRT 5\% 
Jenis hara berpengaruh sangat nyata terhadap bobot total, bobot polybag ${ }^{-1}$, bobot $\operatorname{tanaman}^{-1}$, bobot layak pasar, bobot daun, bobot batang, dan panjang akar (Tabel 11 dan 12). Parameter bobot total, bobot polybag ${ }^{-1}$, bobot layak pasar, bobot akar, dan panjang akar menunjukkan bahwa $\mathrm{AB}$ Mix lebih tinggi dibandingkan dengan NPK 15:15:15 dan NPK 12:14:12. Sementara pada bobot tanaman ${ }^{-1}$, bobot daun, bobot akar, dan warna daun NPK 15:15: tidak berbeda nyata dengan AB Mix.
Frekuensi aplikasi tidak berpengaruh nyata terhadap seluruh parameter pengamatan. Interaksi terjadi pada parameter bobot tanaman ${ }^{-1}$, bobot layak pasar, bobot tidak layak pasar, dan bobot daun. Interaksi terbaik antara jenis hara dan frekuensi aplikasi untuk parameter tinggi tanaman, diameter batang, bobot daun, bobot $\operatorname{tanaman}^{-1}$, dan bobot layak pasar terjadi antara jenis hara $\mathrm{AB}$ Mix dan frekuensi aplikasi 2 kali, meskipun berdasarkan statistik tidak berbeda dengan NPK 15:15:15 dan frekuensi aplikasi 1 kali.

Tabel 11. Pengaruh hara dan frekuensi aplikasi terhadap bobot total, bobot polybag ${ }^{-1}$, bobot tanaman ${ }^{-1}$, bobot layak pasar, dan bobot tidak layak pasar.

\begin{tabular}{|c|c|c|c|c|c|}
\hline \multirow[b]{2}{*}{ Perlakuan } & \multirow{2}{*}{$\begin{array}{c}\text { Bobot } \\
\operatorname{Tanaman}^{-1}(\mathrm{~g})\end{array}$} & \multirow{2}{*}{$\begin{array}{c}\text { Bobot } 4 \\
\text { Tanaman }^{-1} \\
\text { (g) }\end{array}$} & \multicolumn{3}{|c|}{ Bobot 96 Tanaman $(\mathrm{g})$} \\
\hline & & & $\begin{array}{c}\text { Bobot Layak } \\
\text { Pasar }\end{array}$ & $\begin{array}{c}\text { Bobot Tidak Layak } \\
\text { Pasar }\end{array}$ & $\begin{array}{l}\text { Bobot } \\
\text { Total }\end{array}$ \\
\hline \multicolumn{6}{|l|}{ Hara } \\
\hline AB Mix & $20.02 \mathrm{a}$ & $69.26 \mathrm{a}$ & $205.29 a$ & $2.50 \mathrm{~b}$ & $207.79 a$ \\
\hline NPK 15:15:15 & $19.09 \mathrm{a}$ & $57.23 b$ & $130.69 b$ & $41.01 \mathrm{a}$ & $171.70 \mathrm{~b}$ \\
\hline NPK 12:14:12 & $14.40 \mathrm{~b}$ & $47.15 \mathrm{c}$ & $119.38 b$ & $22.09 \mathrm{ab}$ & $141.47 \mathrm{c}$ \\
\hline P-value & $* *$ & $* *$ & $* *$ & $*$ & $* *$ \\
\hline \multicolumn{6}{|l|}{ Frekuensi } \\
\hline 1 kali & 17.16 & 57.87 & 161.02 & 12.59 & 173.61 \\
\hline 2 kali & 18.51 & 57.90 & 142.55 & 31.14 & 173.69 \\
\hline P-value & tn & tn & tn & tn & tn \\
\hline \multicolumn{6}{|l|}{ Interaksi } \\
\hline P-value & $* *$ & tn & $*$ & $*$ & tn \\
\hline $\mathrm{CV}$ & 13.13 & 15.78 & 24.77 & 101.54 & 15.78 \\
\hline
\end{tabular}

Keterangan: angka yang diikuti huruf yang sama pada kolom yang sama tidak berbeda nyata menurut uji DMRT 5\%

Tabel 12. Pengaruh hara dan frekuensi aplikasi terhadap bobot daun, bobot batang, bobot akar, panjangakar, dan warna daun kailan

\begin{tabular}{|c|c|c|c|c|c|}
\hline \multirow{2}{*}{ Perlakuan } & \multicolumn{3}{|c|}{ Bobot Tanaman-1 (g) } & \multirow{2}{*}{$\begin{array}{c}\text { Panjang Akar } \\
(\mathrm{cm})\end{array}$} & \multirow{2}{*}{ Warna Daun } \\
\hline & Daun & Batang & Akar & & \\
\hline \multicolumn{6}{|l|}{ Hara } \\
\hline AB Mix & $14.50 \mathrm{a}$ & $3.49 \mathrm{a}$ & $1.58 \mathrm{a}$ & $13.22 \mathrm{a}$ & $2.96 b$ \\
\hline NPK 15:15:15 & $14.98 \mathrm{a}$ & $2.20 \mathrm{~b}$ & $1.41 \mathrm{ab}$ & $11.39 b$ & $2.96 b$ \\
\hline NPK12:14:12 & $10.84 b$ & $2.07 \mathrm{~b}$ & $1.14 \mathrm{~b}$ & $10.39 b$ & $3.12 \mathrm{a}$ \\
\hline P-value & $* *$ & $* *$ & tn & $* *$ & tn \\
\hline \multicolumn{6}{|l|}{ Frekuensi } \\
\hline 1 kali & 12.96 & 2.42 & 1.34 & 11.75 & 3.03 \\
\hline 2 kali & 13.91 & 2.75 & 1.41 & 11.58 & 3.00 \\
\hline P-value & tn & tn & tn & tn & tn \\
\hline \multicolumn{6}{|l|}{ Interaksi } \\
\hline P-value & $*$ & tn & tn & tn & tn \\
\hline $\mathrm{CV}$ & 16.11 & 20.26 & 23.98 & 11.18 & 4.77 \\
\hline
\end{tabular}

Keterangan: angka yang diikuti huruf yang sama pada kolom yang sama tidak berbeda nyata menurut uji DMRT 5\% 
Tabel 13. Pengaruh interaksi antara jenis hara dan frekuensi aplikasi terhadap tinggi tanaman kailan 2 MST dan 4 MST, diameter batang 4 MST, serta bobot daun

\begin{tabular}{lcccccccc}
\hline & $\begin{array}{c}\text { Tinggi Tanaman 2 } \\
\text { MST }(\mathrm{cm})\end{array}$ & $\begin{array}{c}\text { Tinggi Tanaman 4 } \\
\text { MST }(\mathrm{cm})\end{array}$ & $\begin{array}{c}\text { Diameter Batang 4 } \\
\text { MST }(\mathrm{cm})\end{array}$ & Bobot Daun $(\mathrm{g})$ \\
\cline { 2 - 9 } Jenis hara & $\begin{array}{c}\text { Frekuensi Aplikasi } \\
\text { (kali) }\end{array}$ & $\begin{array}{c}\text { Frekuensi Aplikasi } \\
(\text { kali) }\end{array}$ & $\begin{array}{c}\text { Frekuensi Aplikasi } \\
\text { (kali) }\end{array}$ & $\begin{array}{c}\text { Frekuensi } \\
\text { Aplikasi (kali) }\end{array}$ \\
\cline { 2 - 10 } & 1 & 2 & 1 & 2 & 1 & 2 & 1 & 2 \\
\hline AB Mix & 4.68 & $5.91 \mathrm{a}$ & 9.38 & $11.59 \mathrm{a}$ & 0.36 & 0.34 & $12.43 \mathrm{ab}$ & $16.57 \mathrm{a}$ \\
NPK 15:15:15 & 5.61 & $5.61 \mathrm{a}$ & 9.24 & $8.95 \mathrm{~b}$ & 0.37 & 0.31 & $16.22 \mathrm{a}$ & $13.75 \mathrm{~b}$ \\
NPK 12:14:12 & 4.98 & $4.98 \mathrm{~b}$ & 9.67 & $8.68 \mathrm{~b}$ & 0.37 & 0.32 & $10.25 \mathrm{~b}$ & $11.43 \mathrm{~b}$
\end{tabular}

Keterangan: angka yang diikuti huruf yang sama pada kolom yang sama tidak berbeda nyata menurut uji DMRT 5\%

Tabel 14. Pengaruh interaksi antara jenis hara dan frekuensi aplikasi terhadap bobot tanaman ${ }^{-1}$, bobot layak pasar, dan bobot tidak layak pasar

\begin{tabular}{lcccccc}
\hline \multirow{2}{*}{ Jenis hara } & \multicolumn{2}{c}{ Bobot Tanaman $^{-1}(\mathrm{~g})$} & \multicolumn{2}{c}{ Bobot Layak Pasar $(\mathrm{g})$} & \multicolumn{2}{c}{$\begin{array}{c}\text { Bobot Tidak Layak Pasar } \\
(\mathrm{g})\end{array}$} \\
\cline { 2 - 7 } & \multicolumn{2}{c}{ Frekuensi Aplikasi (kali) } & \multicolumn{2}{c}{ Frekuensi Aplikasi (kali) } & Frekuensi Aplikasi (kali) \\
\cline { 2 - 7 } & 1 & 2 & 1 & 2 & 1 & 2 \\
\hline AB Mix & $17.18 \mathrm{ab}$ & $22.85 \mathrm{a}$ & $64.93 \mathrm{a}$ & $71.93 \mathrm{a}$ & 0.97 & $0.70 \mathrm{~b}$ \\
NPK 15:15:15 & $20.55 \mathrm{a}$ & $17.63 \mathrm{~b}$ & $57.01 \mathrm{a}$ & $30.12 \mathrm{~b}$ & 4.03 & $23.32 \mathrm{a}$ \\
NPK 12:14:12 & $13.76 \mathrm{~b}$ & $15.05 \mathrm{~b}$ & $39.08 \mathrm{~b}$ & $40.89 \mathrm{~b}$ & 7.60 & $7.13 \mathrm{~b}$ \\
\hline
\end{tabular}

Keterangan: angka yang diikuti huruf yang sama pada kolom yang sama tidak berbeda nyata menurut uji DMRT 5\%

\section{Kangkung periode II}

Tabel 15 dan tabel 16 menunjukkan bahwa perlakuan jenis hara berpengaruh nyata pada tinggi tanaman 2 MST, diameter batang 2 MST dan 3 MST, lebar daun 1-3 MST, dan jumlah daun 2 dan 3 MST. Perlakuan NPK 15:15:15 memiliki tinggi tanaman, diameter batang, dan lebar daun yang tidak berbeda nyata dengan $\mathrm{AB}$ Mix, tetapi berbeda nyata dengan NPK 12:14:12. Jumlah daun terbanyak yaitu perlakuan NPK 15:15:15, sedangkan AB Mix dan NPK 12:14:12 memiliki jumlah daun yang tidak berbeda nyata. Berdasarkan tabel 17 perlakuan jenis hara NPK 15:15:15 memiliki bobot tanaman ${ }^{-1}$, bobot/4 tanaman, bobot layak pasar tertinggi, dan warna daun yang lebih hijau dibandingkan $\mathrm{AB}$ Mix dan NPK 12:14:12.

Tabel 15. Pengaruh hara dan frekuensi aplikasi terhadap panjang daun dan jumlah daun kangkung II

\begin{tabular}{|c|c|c|c|c|c|c|}
\hline \multirow{2}{*}{ Perlakuan } & \multicolumn{3}{|c|}{ Tinggi Tanaman $(\mathrm{cm})$} & \multicolumn{3}{|c|}{ Diameter Batang $(\mathrm{cm})$} \\
\hline & $1 \mathrm{MST}$ & $2 \mathrm{MST}$ & $3 \mathrm{MST}$ & $1 \mathrm{MST}$ & $2 \mathrm{MST}$ & $3 \mathrm{MST}$ \\
\hline \multicolumn{7}{|l|}{ Hara } \\
\hline AB Mix & 16.62 & $28.38 \mathrm{a}$ & 34.92 & 0.35 & $0.47 \mathrm{a}$ & $0.51 \mathrm{a}$ \\
\hline NPK $15: 15: 15$ & 16.50 & $29.35 \mathrm{a}$ & 34.85 & 0.36 & $0.45 \mathrm{a}$ & $0.49 a$ \\
\hline NPK 12:14:12 & 15.39 & $25.84 b$ & 29.88 & 0.34 & $0.42 b$ & $0.45 b$ \\
\hline P-value & $\operatorname{tn}$ & $*$ & $\operatorname{tn}$ & tn & $* *$ & $*$ \\
\hline \multicolumn{7}{|l|}{ Frekuensi } \\
\hline $1 \mathrm{kali}$ & $15.30 \mathrm{~b}$ & $26.79 b$ & 33.15 & 0.35 & 0.44 & 0.48 \\
\hline 2 kali & $17.04 \mathrm{a}$ & $28.92 \mathrm{a}$ & 33.28 & 0.35 & 0.45 & 0.48 \\
\hline P-value & $* *$ & $*$ & tn & tn & tn & tn \\
\hline \multicolumn{7}{|l|}{ Interaksi } \\
\hline P-value & tn & tn & $\operatorname{tn}$ & tn & tn & tn \\
\hline $\mathrm{CV}$ & 6.82 & 8.51 & 15.52 & 5.47 & 5.92 & 7.74 \\
\hline
\end{tabular}

Keterangan: angka yang diikuti huruf yang sama pada kolom yang sama tidak berbeda nyata menurut uji DMRT 5\% 
Tabel 16. Pengaruh hara dan frekuensi aplikasi terhadap panjang daun dan jumlah daun kangkung II

\begin{tabular}{|c|c|c|c|c|c|c|}
\hline \multirow{2}{*}{ Perlakuan } & \multicolumn{3}{|c|}{ Lebar Daun $(\mathrm{cm})$} & \multicolumn{3}{|c|}{ Jumlah Daun (helai) } \\
\hline & $1 \mathrm{MST}$ & $2 \mathrm{MST}$ & $3 \mathrm{MST}$ & $1 \mathrm{MST}$ & $2 \mathrm{MST}$ & $3 \mathrm{MST}$ \\
\hline \multicolumn{7}{|l|}{ Hara } \\
\hline AB Mix & $1.60 \mathrm{ab}$ & $1.88 \mathrm{ab}$ & $1.97 \mathrm{ab}$ & 8.25 & $12.13 b$ & $14.88 b$ \\
\hline NPK 15:15:15 & $1.71 \mathrm{a}$ & $2.06 \mathrm{a}$ & $2.10 \mathrm{a}$ & 8.38 & $14.96 \mathrm{a}$ & $19.88 \mathrm{a}$ \\
\hline NPK 12:14:12 & $1.51 \mathrm{~b}$ & $1.72 b$ & $1.80 \mathrm{~b}$ & 8.17 & $11.46 \mathrm{~b}$ & $13.79 b$ \\
\hline P-value & $*$ & $* *$ & $*$ & tn & $* *$ & $* *$ \\
\hline \multicolumn{7}{|l|}{ Frekuensi } \\
\hline $1 \mathrm{kali}$ & 1.58 & 1.87 & 1.93 & 8.06 & 12.44 & $15.36 \mathrm{~b}$ \\
\hline 2 kali & 1.64 & 1.91 & 1.98 & 8.47 & 13.25 & $17.00 \mathrm{a}$ \\
\hline $\mathrm{P}$-value & tn & $\operatorname{tn}$ & tn & tn & $\operatorname{tn}$ & $*$ \\
\hline \multicolumn{7}{|l|}{ Interaksi } \\
\hline P-value & tn & tn & tn & tn & tn & tn \\
\hline $\mathrm{CV}$ & 9.12 & 9.70 & 8.85 & 7.60 & 8.31 & 11.56 \\
\hline
\end{tabular}

Keterangan: angka yang diikuti huruf yang sama pada kolom yang sama tidak berbeda nyata menurut uji DMRT 5\%.

Tabel 17. Pengaruh hara dan frekuensi aplikasi terhadap bobot daun, bobot batang, bobot akar, panjang akar, dan warna daun kangkung II

\begin{tabular}{|c|c|c|c|c|c|c|}
\hline \multirow[b]{2}{*}{ Perlakuan } & \multirow[b]{2}{*}{$\begin{array}{c}\text { Bobot } \\
\text { Tanaman }^{-1} \\
(\mathrm{~g})\end{array}$} & \multirow[b]{2}{*}{$\begin{array}{l}\text { Bobot } 4 \\
\text { Tanaman }^{-1} \\
\quad(\mathrm{~g})\end{array}$} & \multicolumn{3}{|c|}{ Bobot 96 Tanaman $(\mathrm{g})$} & \multirow[b]{2}{*}{$\begin{array}{l}\text { Warna } \\
\text { Daun }\end{array}$} \\
\hline & & & $\begin{array}{l}\text { Bobot } \\
\text { Layak } \\
\text { Pasar }\end{array}$ & $\begin{array}{l}\text { Bobot tidak } \\
\text { Layak Pasar }\end{array}$ & $\begin{array}{l}\text { Bobot } \\
\text { Total }\end{array}$ & \\
\hline \multicolumn{7}{|l|}{ Hara } \\
\hline AB Mix & $9.74 b$ & $32.20 \mathrm{~b}$ & $27.58 b$ & 69.02 & $96.60 \mathrm{~b}$ & $2.83 \mathrm{~b}$ \\
\hline NPK $15: 15: 15$ & $12.87 \mathrm{a}$ & $41.05 \mathrm{a}$ & $53.57 \mathrm{a}$ & 69.59 & $123.16 \mathrm{a}$ & $3.29 \mathrm{a}$ \\
\hline NPK 12:14:12 & $7.01 \mathrm{c}$ & $24.26 \mathrm{c}$ & $2.70 \mathrm{c}$ & 70.07 & $72.77 \mathrm{c}$ & $2.58 \mathrm{~b}$ \\
\hline P-value & $* *$ & $* *$ & $* *$ & $\operatorname{tn}$ & $* *$ & $* *$ \\
\hline \multicolumn{7}{|l|}{ Frekuensi } \\
\hline 1 kali & 9.61 & 31.79 & 25.41 & 69.95 & 95.36 & 2.94 \\
\hline 2 kali & 10.14 & 33.22 & 30.49 & 69.17 & 99.66 & 2.86 \\
\hline P-value & $\operatorname{tn}$ & $\operatorname{tn}$ & $\operatorname{tn}$ & $\operatorname{tn}$ & $\operatorname{tn}$ & $\operatorname{tn}$ \\
\hline \multicolumn{7}{|l|}{ Interaksi } \\
\hline $\mathrm{P}$-value & tn & tn & tn & tn & tn & tn \\
\hline $\mathrm{CV}$ & 15.82 & 13.32 & 55.75 & 16.90 & 13.30 & 13.13 \\
\hline
\end{tabular}

Keterangan: angka yang diikuti huruf yang sama pada kolom yang sama tidak berbeda nyata menurut uji DMRT $5 \%$.

Perlakuan jenis hara tidak memberikan pengaruh yang nyata terhadap bobot tidak layak pasar kangkung. Perlakuan jenis hara NPK 12:14:12 untuk parameter bobot tanaman ${ }^{-1}$, bobot 4 tanaman $^{-1}$, dan bobot layak pasar yang terkecil diantara NPK 15:15:15 dan AB Mix, namun warna daun dengan perlakuan NPK 12:14:12 tidak berbeda nyata dengan AB Mix.

\section{KESIMPULAN}

Pupuk majemuk NPK 15:15:15 dengan konsentrasi $\mathrm{N}$ yang telah disetarakan dengan larutan hara AB Mix dapat digunakan sebagai sumber hara pada budidaya kangkung, caisin, dan kailan secara hidroponik. Tanaman kangkung periode I dan periode II yang diberi perlakuan hara NPK 15:15:15 memiliki pertumbuhan vegetatif dan hasil panen yang sama dengan tanaman dengan perlakuan AB Mix. Sama halnya dengan kangkung, pertumbuhan vegetatif dan hasil panen caisin yang diberi perlakuan NPK 15:15:15 tidak berbeda nyata dengan AB Mix. Lain halnya dengan kailan, walaupun pertumbuhan vegetatif dengan perlakuan NPK 15:15:15 tidak berbeda dengan $\mathrm{AB}$ Mix, namun untuk hasil panen cenderung 
lebih rendah dibanding $\mathrm{AB}$ Mix. Hal tersebut dikarenakan pada saat menjelang panen, tanaman kailan mendapatkan serangan kutu kebul. Berdasarkan analisis usaha tani, biaya produksi NPK 15:15:15 lebih murah dibandingkan $A B$ Mix dan dari segi kemudahan NPK 15:15:15 lebih mudah didapatkan dibandingkan hara AB Mix. Pupuk majemuk NPK 12:14:12 tidak dapat menggantikan $\mathrm{AB}$ Mix karena menghasilkan tanaman dengan kualitas yang paling rendah serta biaya produksi yang lebih mahal. Frekuensi aplikasi 2 kali menghasilkan tanaman yang lebih baik dibandingkan frekuensi aplikasi 1 kali, walaupun berdasarkan nilai statistik tidak berbeda nyata antara frekuensi aplikasi 1 kali dengan frekuensi aplikasi 2 kali. Kombinasi perlakuan larutan hara AB Mix dengan frekuensi aplikasi 2 kali menghasilkan tinggi tanaman $11.59 \mathrm{~cm}$, bobot tanaman ${ }^{-1} 22.85$ gram, bobot layak pasar 71.93 gram, dan bobot daun tertinggi sebesar 16.57 gram.

\section{SARAN}

Perlu penelitian lebih lanjut dengan frekuensi aplikasi yang lebih beragam. Selain itu perlu dilakukan penelitian lanjutan untuk mencari kombinasi pupuk majemuk dengan kandungan NPK mendekati AB Mix.

\section{DAFTAR PUSTAKA}

Badan Pusat Statistik. 2012. Produksi Sayuran Indonesia Tahun 2010-2011. Badan Pusat Statistik. Jakarta.

Capinera, J.L. 2001. Handbook of Vegetable Pests. Academic Press. Orlando. US.

Kusumawardhani, A., W.D. Widodo. 2003. Pemanfaatan pupuk majemuk sebagai sumber hara budidaya tomat secara hidroponik. Bul. Agron. 31(1): 15-20.
Iqbal, M. 2006. Penggunaan pupuk majemuk sebagai sumber hara pada budidaya bayam secara hidroponik dengan tiga cara fertigasi. Skripsi. Program Studi Agronomi. Fakultas Pertanian. Institut Pertanian Bogor. Bogor.

Marwan, M. 2008. Kajian permasalahan penerapan manajemen mutu terpadu (Kasus: CV. Putri Segar Lembang, Jawa Barat). Skripsi. Program Sarjana Manajemen Agribisnis. Fakultas Pertanian. Institut Pertanian Bogor. Bogor.

Masriah, N. 2006. Penggunaan pupuk majemuk sebagai sumber hara pada budidaya kangkung (Ipomoea reptans Poir) secara hidroponik dengan tiga cara fertigasi. Skripsi. Departemen Agronomi dan Hortikultura. Fakultas Pertanian. Institut Pertanian Bogor. Bogor.

Munawar, A. 2011. Kesuburan Tanah dan Nutrisi Tanaman: IPB Press. Bogor.

Noor, Z. 2006. Pengaruh frekuensi penyiraman nutrisi terhadap produktivitas dan mutu hasil panen paprika. Disertasi. Departemen Budidaya Pertanian. Institut Pertanian Bogor. Bogor.

Resh, H.M. 2004. Hydroponic Food Production: A Definitive Guidebook of Soiless Food-Growing Methods. $6^{\text {th }} \mathrm{Ed}$. Newconcept Pr, Inc. New Jersey. US.

Salisbury, F.B., C.W. Ross. 1995. Fisiologi Tumbuhan Dasar Jilid I. Penerbit ITB. Bandung.

Susila, A.D. 2006. Fertigasi pada Budidaya Tanaman Sayuran di dalam Greenhouse. Direktorat Jenderal Hortikultura. Bandung. 